
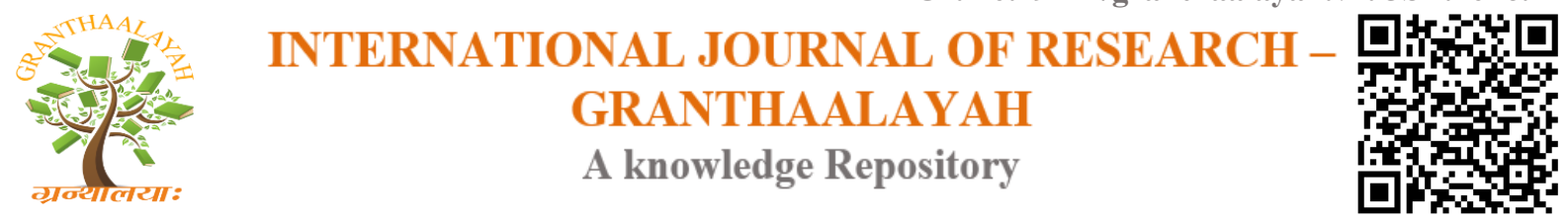

Management

\title{
ENTREPRENEURSHIP - A KEY FOR WOMEN EMPOWERMENT
}

\author{
Dr. C. Eugine Franco ${ }^{* 1}$, Sharmi Selvakumar ${ }^{2}$ \\ ${ }^{* 1}$ HOD of Commerce, St. Xavier's College (Autonomous), Palayamkottai, INDIA \\ ${ }^{2}$ Ph.D Research Scholar (FT), Commerce Research Center, St. Xavier's College (Autonomous), \\ Palayamkottai, INDIA
}

\begin{abstract}
Entrepreneurship is the core of economic development. It is a multi-dimensional task and essentially creative activity. Entrepreneur is key factor of entrepreneurship. Entrepreneurship has been a male-dominated phenomenon from the very early age but time has changed the situation and brought women as today's most memorable and inspirational entrepreneurs. The position and status of women in any society is an index of its civilization and progress. Women are equally competent in running business but still lacks behind in spite of women empowerment movement in our country, there are social, cultural and economic hurdles in the way of women entrepreneurship and the major problem is lack of entrepreneurial environment. In spite of having the potential and talent, women are deprived of opportunities, information and education. The paper talks about the status of women entrepreneurs and also analyze the factors which motivates women to start their own venture and the problems faced by them when they ventured out to carve their own niche in the competitive world of business environment. An attempt is made to understand the role of government to accelerate the growth of women entrepreneurship.
\end{abstract}

Keywords:

Entrepreneurship development, Women entrepreneurs, problems, Women Empowerment.

Cite This Article: Dr. C. Eugine Franco, and Sharmi Selvakumar, "ENTREPRENEURSHIP - A KEY FOR WOMEN EMPOWERMENT" International Journal of Research - Granthaalayah, Vol. 4, No. 3: SE (2016): 45-51.

\section{INTRODUCTION}

Entrepreneurs play very important role in socio-economic welfare of the country. They identify the needs of the business, purchase the other factors of production and coordinate them for some productive purposes. They are the innovators, researchers and risk-takers of the company. Today business is built around human capital and women are one of the valuable factors. Globalization and Liberalization of market encouraged women to come forward to become an entrepreneur and start new industries. 
A role of modern women is not confined to the traditional role as a mother and housewife; it has and is undergoing changes. As woman gets educated she begins to think of herself as an independent person, she becomes aware of her own identity, potentials and decision making capabilities. Interested women with creative and innovative ideas are coming forward to start the small and medium sized enterprises. It is a common assumption that majority of women in India are economically non-productive as they are not involved in activities that are financially remunerative. But this trend is gradually changing. Today's women are taking more and more professional and technical degrees to cope up with market need and are flourishing as designers, interior decorators, exporters, publishers, garment manufacturers and still exploring new avenues of economic participation. It is perhaps for these reasons that Government Bodies, NGO's, Social Scientists, Researchers and International Agencies have started showing interest in the issues related to entrepreneurship among women in India.

At the same time, it is also recognized that their challenges are immense and complex. For women entrepreneurs, starting and operating a business involves considerable risks and difficulties, because in the Indian social environment women has always lived as subordinate to men. There have been noticeable changes in the socio-psycho-cultural and economic norms of our society due to liberalized policy of the government of India, increase in the education levels of women and increased social awareness in respect of the role women plays in the society. It has now been recognized that to promote self-employment and to reduce the incidence of poverty, some drastic efforts have to be made to accelerate self-employment of women in various sectors.

\section{OBJECTIVES OF THE STUDY}

The present study aims at fulfilling the following objectives.

- To explore the reasons why women start business of their own.

- To study the characteristics of women entrepreneurs.

- To critically examine the types of issues and problems they encounter in order to reach the level of success.

- To suggest different remedial measures in helping and accelerating women entrepreneurs.

\section{REASONS FOR WOMEN BECOMING ENTREPRENEURS}

The glass ceilings are shattered and women are found indulged in every line of business. The entry of women into business in India is traced out as an extension of their kitchen activities, mainly 3P's, Pickle, Powder and Pappad. But with the spread of education and passage of time women started shifting from 3P's to modern 3E's i.e., Energy, Electronics and Engineering. Skill, knowledge and adaptability in business are the main reasons for women to emerge into business ventures.. A strong desire to do something positive is an inbuilt quality of entrepreneurial women, who is capable of contributing values in both family and social life. With the advent of media, women are aware of their own traits, rights and also the work situations. The challenges and opportunities provided to the women of digital era are growing rapidly that optimum use of technical education \& qualifications. 
The job seekers are turning into job creators. Many women start a business due to some traumatic event, such as divorce, discrimination due to pregnancy or the corporate glass ceiling, the health of a family member, or economic reasons such as a layoff. But a new talent pool of women entrepreneurs is forming today, as more women opt to leave corporate world to chart their own destinies: To achieve for independence \& flexibility, To better balance work \& family, To make optimum use of technical education \& qualifications. The following are the reasons for women becoming entrepreneurs:

- Women are better connectors.

- Women are better at multitasking.

- Women are perfectionists.

- Women take others into consideration.

- Women think success comes from hard work not just from being "awesome."

- Women share the credit.

- Women second guess themselves.

- Women don't take as many risks.

- Women don't fiercely negotiate for the best they can get.

- Women value their life outside of work.

\section{CHARACTERISTICS OF WOMEN ENTREPRENEURS}

Women entrepreneurs tend to be highly motivated \& self-directed, they also exhibit a high internal locus of control \& achievement. Researchers contend that women business owners possess certain specific characteristics that promote their creativity and generate new ideas and ways of doing things. One key characteristic of all successful entrepreneurs is that they have vision. They find a niche in a particular market and find a way to fill it. They give life to their vision/business and either personally or finding a way to make it happen. This "vision" keeps them focused and able to bring product or service to the market.

Entrepreneurs are also very self-motivated. They don't wait for someone to tell them to get to work. They are self-propelled and do the work because they want to. They know that it takes discipline and self-sacrifice to make their dreams come true. Think hard before you decided to quit your present job and start your own business. It's doable but not without many sacrifices. Still, the rewards can be great if you're willing to put in the effort. Sharp Communication skills, Good interpersonal skills, Consensus building competencies, Very High level of Emotional Quotient, Good decision making capabilities.

\section{PROBLEMS OF WOMEN ENTREPRENEURSHIP IN INDIA}

PROBLEM OF FINANCE: Finance is regarded as "life blood" for any enterprise, be it big or small. However, women entrepreneurs suffer from shortage of finance on two counts. Firstly, women do not generally have property on their names to use them as collateral for obtaining funds from external sources. Thus, their access to the external sources of funds is limited. Secondly, the banks also consider women less credit- worthy and discourage women borrowers on the belief that they can at any time leave their business. Given such situation, women entrepreneurs are bound to rely on their own savings, if any and loans from 
friends and relatives who are expectedly merger and negligible. Thus, women enterprises fail due to the shortage of finance.

SCARCITY OF RAW MATERIAL: Most of the women enterprises are plagued by the scarcity of raw material and necessary inputs. It is added to this are the high prices of raw material, on the other.

STIFF COMPETITION: Women entrepreneurs do not have organization set- up to pump in a lot of money for canvassing and advertisement. Thus, they have to face a stiff competition for marketing their products with both organized sector and their male counterparts. Such a competition ultimately results in the liquidation of women enterprises.

FAMILY TIES: In India, it is mainly a woman's duty to look after the children and other members of the family. Man plays a secondary role only. In case of married woman, she has to strike a fine balance between her business and family. Her total involvement in family leaves little or no energy and time to devote for business. Support and approval of husbands seem necessary condition or women's entry in to business. Accordingly, the educational level and family background of husbands positively influence women's entry into business activities.

LACK OF EDUCATION: In India, majority of women are still illiterate. Illiteracy is the root cause of socio- economic problems. Due to the lack of education, women are not aware of business, technology and market knowledge. Also, lack of education cases low achievement motivation among women. Thus, lack of education creates problems for women in the setting up and running of business enterprises.

MALE DOMINATED SOCIETY: Male chauvinism is till the order of the day in India. The constitution of India speaks of equality between genders. But, in practice women are looked upon as able i.e. weak in all respects. Women suffer from male reservations about a women's role, ability and capacity and are treated accordingly. In nutshell, in the male dominated Indian society, women are not treated equal to men. This in turn, serves as a barrier to women entry into business.

LOW RISK- BEARING ABILITY: Women in India lead a protected life. They are less educated and economically not self- dependent. All these reduce their ability to bear risk involved in running an enterprise. Risk bearing is an essential requisite of a successful entrepreneur. In addition to above problems, inadequate infra structural facilities, shortage of power, high cost of production, social attitude, low need for achievement and socio- economic constraints also hold the women back from entering into business.

FINANCIAL PROBLEMS: Finance is a most important aspect of any business. Non- availability of long-term finance, regular and frequent need of working capital and long procedure to avail financial help is found to be the financial problems faced by women. 
MARKETING PROBLEMS: During the process of marketing of products women entrepreneurs faced certain problems viz. poor location of shop, lack of transport facility and tough competition from larger and established units.

PRODUCTION PROBLEMS: Production problems faced by maximum women are non-availability of raw material. Non-availability of raw material is one of the reasons to the slow growth of women entrepreneurs. Other production problems are non-availability of machine or equipment, lack of training facility and non-availability of labour, high cost of required machine or equipment.

HEALTH PROBLEMS: Major health problems faced by women entrepreneurs were tension, backache, eyestrain fatigue and headache. It is found that women feeling the problem of feeling fatigued after returning home, lack of rest and sleep and heavy schedule.

\section{SUGGESTIONS FOR THE GROWTH OF WOMEN ENTREPRENEURS}

Right efforts from all areas are required in the development of women entrepreneurs and their greater participation in the entrepreneurial activities. The following measures are suggested to empower the women to seize various opportunities and face challenges in business.

- There should be a continuous attempt to inspire, encourage, motivate and cooperate women entrepreneurs.

- An Awareness programme should be conducted on a mass scale with the intention of creating awareness among women about the various areas to conduct business.

- Attempts should be there to enhance the standards of education of women in general as well making effective provisions for their training, practical experience and personality development programmes, to improvise their over-all personality standards.

- Organize training programmes to develop professional competencies in managerial, leadership, marketing, financial, production process, profit planning, maintaining books of accounts and other skills. This will encourage women to undertake business.

- Vocational training to be extended to women community that enables them to understand the production process and production management.

- Educational institutes should tie up with various government and nongovernment agencies to assist in entrepreneurship development mainly to plan business projects.

- International, National, Local trade fairs, Industrial exhibitions, seminars and conferences should be organized to help women to facilitate interaction with other women entrepreneurs.

- Women in business should be offered soft loans \& subsides for encouraging them into industrial activities. The financial institutions should provide more working capital assistance both for small scale venture and large scale ventures.

- Making provision of micro credit system and enterprise credit system to the women entrepreneurs at local level.

- The weaker section could raise funds through various schemes and incentives provided by the government to develop entrepreneurs in the state. E.g. the Prime ministers Rozgar Yojana, The Khadi and Rural village industries scheme, etc. 
- In the initial stages women entrepreneurs may face problems but they must persevere, believe in themselves and not give up mid-way.

- Attempts by various NGO's and government organizations to spread information about policies, plans and strategies on the development of women in the field of industry, trade and commerce. Women entrepreneurs should utilize the various schemes provided by the Government.

- Women should try to upgrade themselves in the changing times by adapting the latest technology benefits. Women must be educated and trained constantly to acquire the skills and knowledge in all the functional areas of business management. This can facilitate women to excel in decision making process and develop a good business network.

- Self-help groups of women entrepreneurs to mobilize resources and pooling capital funds, in order to help the women in the field of industry, trade and commerce can also play a positive role to solve this problem.

- To establish all India forums to discuss the problems, grievances, issues, and filing complaints against constraints or shortcomings towards the economic progress path of women entrepreneurs and giving suitable decisions in the favour of women entrepreneurs and taking strict stand against the policies or strategies that obstruct the path of economic development of such group of women entrepreneurs.

\section{CONCLUSION}

The emergence of women entrepreneurs and their contribution to the national economy is quite visible in India. The glass ceilings are shattered and women are found to be indulged in every line of business from papad to power cables. Even though we have many successful Women Entrepreneurs in our country, but still we have a male dominated culture there are many challenges which women entrepreneurs face from family \& Society.

Since 1980 the government of India has shown increasing concern for women issues through a variety of legislations promoting the education and political participation of women. There should also be efforts from all sectors to encourage the economic participation of women. Along with adequate training, institutional and financial support as a composite package needs to be encouraged. It can be said that today we are in a better position wherein women participation in the field of entrepreneurship is increasing at considerable rate, efforts are being taken at the economy as well as global level to enhance woman's involvement in the enterprise sector. This is mainly because of attitude change, diverted conservative mindset of society to modern one, daring and risk-taking abilities of women, support and cooperation by society members, changes and relaxations in government policies, granting various upliftment schemes to women entrepreneurs etc.

\section{REFERENCES}

[1] Bhatia Anju (2000) "Women Development and NGOs". Rawat Publication, New Delhi.

[2] Bharati Collen \&Indira Parikh(2005) "A Reflection of Indian Women in the Entrepreneurial World., Indian Institute of Management, Ahmadabad, Working paper Number 2005-08-07. 
[3] David H.Holt (2003), ,Entrepreneurship New Venture Creation., prentice-Hall India.

[4] Hattangadi V, (2007), „Entrepreneurship -Need of the hour. Himalaya Publishing House.

[5] Helene Ahl "Why Research on Women Entrepreneurs Needs New Directions", Entrepreneurship Theory and Practice Volume 30 Issue 5.

[6] Lalita .N, (2005) "Micro Finance and Rural Development", Gandhi gram Rural Institute, Gandhi gram, Dindigal, Tamilnadu.

[7] Ram Naresh Thakur (2009). "Rural Women Empowerment in India" in Empowerment of Rural Women in India Kanishka Publishers, New Delhi.

[8] Ramchandran. K. "Entrepreneurship Development-Indian Cases on Change Agents., Tata McGraw-Hill Publication company ltd

[9] Ramesh Bhandari (2010), Entrepreneurship and Women Empowerment. Alfa Publications, bearing ISBN: 978-93-80096-72-8.

[10] Sanjay Tiwari and Anshuja Tiwari, (2007), "Women Entrepreneurship and economic Development.1st Edition published by Sarup and Sons, New Delhi

[11] Soundarapandian.M.(2008), Women Entrepreneurship-Issues and Strategies. Published by Kanishka Publishers distributors, ISBN 978-81-7391-314-5.

[12] http://www.ijmra.us/project\%20doc/IJPSS_MARCH2012/IJMRA-PSS862.pdf

[13] http://www.hgsitebuilder.com/files/writeable/uploads/hostgator47959/file/ijars189.pdf

[14] http://www.idosi.org/mejsr/mejsr18(8)13/21.pdf

[15] http://zenithresearch.org.in/images/stories/pdf/2011/Sep/14.Vol_01_Issue_05\%20MEEN U\%20GOYAL\%20women\%20paper.pdf

[16] http://rcmss.com/lijdds/Women\%20Entrepreneurship\%20Issues, \%20Challenges\%20and $\% 20$ Empowerment\%20through\%20Self\%20help\%20Groups_\%20An\%20Overview\%20o f\%20Himachal\%20Pradesh..pdf

[17] http://ijbssnet.com/journals/Vol_3_No_23_December_2012/18.pdf

[18] http://www.irjcjournals.org/ijmssr/feb2013/2.pdf

[19] http://prj.co.in/setup/socialscience/paper62.pdf

[20] http://inpressco.com/wp-content/uploads/2014/07/Paper254-57.pdf

[21] http://www.oecd.org/cfe/smes/31919215.pdf 